\title{
Game Mophy (Monopoly Physics) Sebagai Alternatif Media Pembelajaran Fisika untuk Meningkatkan Penguasan Konsep Siswa
}

\author{
${ }^{1}$ Andista Candra Yusro, ${ }^{1} P$ Purwandari*, ${ }^{1}$ Tria Nanditasari \\ 1 Prodi Pendidikan Fisika, Universitas PGRI Madiun, Jl. Setiabudi No.85 Madiun 63118, Indonesia. \\ e-mail: andista@unipma.ac.id; *purwandari@unipma.ac.id; trianandita0@gmail.com
}

\begin{abstract}
Abstrak
Tujuan penelitian ini untuk mengetahui langkah-langkah pengembangan media mophy, dan untuk mengetahui peningkatan penguasaan konsep fisika siswa SMK. Research and Development (R\&D) adalah jenis penelitian yang digunakan oleh peneliti dan model penelitian yang digunakan adalah model ADDIE. Sampel penelitian ini adalah siswa kelas X C1 SMK Model PGRI 1 Mejayan sebanyak 30 siswa. Langkah-langkah ADDIE yang dilakukan yaitu analisis kebutuhan, merancang desain mophy, validasi desain, mengembangkan produk mophy, validasi desain media, uji coba lapangan dan evaluasi kegiatan pembelajaran. Penelitian dilaksanakan di SMK Model PGRI 1 Mejayan. Teknik pengumpulan data yang digunakan adalah wawancara, angket, tes dan dokumentasi. Hasil uji kualitas media mophy yang dilakukan oleh ahli media berdasarkan hasil validasi memperoleh rata-rata persentase sebesar $66,75 \%$ media layak untuk digunakan, sedangkan berdasarkan angket respon siswa memperoleh rata-rata persentase sebesar $77,706 \%$. Rata-rata nilai penguasaan konsep siswa sebelum menggunkan media mophy 57,33 meningkat menjadi 73,42 setelah menggunakan media mophy dengan rata-rata nilai $\mathrm{n}$-gain sebesar 0,38 dalam kategori sedang. Mophy memberikan pengaruh positif terhadap peningkatkan penguasaan konsep siswa siswa kelas $X$ SMK Model PGRI 1 Mejayan.
\end{abstract}

Kata Kunci: media pembelajaran; mophy; penguasan konsep.

\section{Game Mophy (Monopoly Physics) as an Alternative Physics Learning Media to Improve Students' Mastery of Concepts}

\begin{abstract}
This study aimed to determine the steps of mophy media development and determine the increase in vocational students' mastery of physics concepts. Research and Development (R\&D) is a type of research used by researchers, and the research model used is the ADDIE model. The sample of this research was 30 students of class X C1 SMK Model PGRI 1 Mejayan. ADDIE steps taken are needs analysis, designing mophy designs, design validation, developing mophy products, validating media designs, field trials, and evaluating learning activities. The research was conducted at SMK Model PGRI 1 Mejayan. The data collection techniques used were interviews, questionnaires, tests, and documentation. The results of the mophy media quality test conducted by media experts based on the validation results obtained an average percentage of $66.75 \%$ of the media suitable for use. Based on the student response questionnaire, the average percentage was $77.706 \%$. The average value of students' mastery of concepts before using mophy media 57.33 increased to 73.42 after using mophy media with an average n-gain value of 0.38 in the moderate category. Mophy has a positive influence on
\end{abstract}

Keywords: learning Media; mophy; mastery of concepts.

How to Cite: Yusro, A., Purwandari, P., \& Nanditasari, T. (2019). Game Mophy (Monopoly Physics) Sebagai Alternatif Media Pembelajaran Fisika untuk Meningkatkan Penguasan Konsep Siswa. Jurnal Pendidikan Fisika dan Keilmuan (JPFK), 5(2), 101-108. doi:http://dx.doi.org/10.25273/jpfk.v5i2.7371 


\section{PENDAHULUAN}

Sebuah proses pembelajaran dirancang sebelumnya untuk menghasilkan tujuan pembelajaran yang telah ditentukan dan sesuai dengan target. Kegiatan pembelajaran yang terjadi penentu hasil belajar yang dicapai oleh siswa, baik itu ranah kognitif, afektif maupun psikomotorik. Semakin bermutu pembelajaran yang dilakukan maka hasil pembelajaran yang dicapai juga semakin optimal. Media pembelajaran memiliki peran yang optimal dalam kesukseskan pencapaian dari tujuan pembelajaran yang telah ditetapkan (Arsyad, 2011). Kesan sulit dan menyeramkan dalam pembelajaran fisika hendaknya dapat dirubah dengan kemasan pembelajaran menarik dan menyenangkan (Sukmawati, 2017; Yuniati, 2011), hal tersebut dapat dilakukan dengan mengkombinasikan antara pembelajaran fisika dengan pendekatan permainan dalam pembelajaran. Mengemas pembelajaran fisika dalam bentuk game sangat mungkin dilakukan oleh guru dikelas (Eberly, 2010) dengan kemasan yang menarik dengan tujuan untuk membantu meningkatkan pemahaman siswa.

Ketersedian media pembelajaran fisika interaktif di sekolah sangat terbatas, dalam belajar fisika siswa melakukannya secara teori dan praktikum di laboratorium. Selain disekolah, ketersedian media pembelajaran fisika interaktif di toko-toko buku juga jarang ditemui, hal ini didasarkan dari hasil survey di toko buku yang ada. Salah satu alternatif yang coba ditawarkan sebagai media pembelajaran fisika di SMK ialah monopoli. Permainan monopoli merupakan salah permainan yang terkenal didunia. Menurut (Purwanto dkk., 2012) beberapa karakteristik dari permainan monopoli yakni memperkenalkan sesuatu yang ada di sekitar kita dengan menggunakan kartu-kartu seperti kartu kompleks tanah, kartu dana umum, kartu kesempatan dll. Permainan tersebut yang akan dimodifikasi sehingga dapat digunakan dalam pembelajaran fisika.

Pembelajaran IPA khususnya fisika akan lebih menarik jika dikemas dengan bentuk permainan, salah satu permainan yang dimanfaatkan adalah monopoli. Permainan monopoli telah banyak diimplemantasikan dalam pembelajaran IPA dan Fisika dijenjang SMP dan SMA dengan hasil yang memuaskan (Purwanto dkk., 2012; Ramadhani \& Wahyuni, 2016; Rofiqoh dkk., 2015). Siswa antusias dalam pembelajaran dan menghasilkan interaksi belajar yang baik antara guru dengan siswa dan antara sesama siswa. Hal ini yang mejadi dasar untuk mencoba menerapkan media Game Mophy dalam pembelajaran fisika di tingkat SMK.

Berdasarkan hasil observasi dan wawancara dengan salah satu guru fisika SMK Model PGRI 1 Mejayan, diketahui bahwa kegiatan pembelajaran fisika yang terjadi di kelas, belum sepenuhnya menggunakan media pembelajaran. Guru hanya menggunakan bank soal, buku serta papan tulis, penggunaan media pembelajaran melalui LCD juga jarang diterapkan. Pada SMK terdapat pelajaran produktif, dimana pelajaran produktif ialah pelajaran yang memuat pelajaran sesuai kejuruan yang dipilih. Jumlah jam pelajaran produktif pada siswa SMK lebih banyak dibandingkan mata pelajaran normatif seperti fisika, matematika, biologi dan lain sebagainya. Siswa SMK cenderung lebih fokus pada pelajaran produktif daripada mata pelajaran lain seperti fisika, karena mata pelajaran produktif dianggap lebih fokus ke bidang keahlian sesuai dengan kejuruan yang dipilih. Interaksi antara guru dan murid dibutuhkan dalam mencapai sebuah tujuan pembelajaran (Sullivan \& Puntambekar, 2019). Konsep pembelajaran IPA dalam hal ini fisika harus didekatkan dengan kehidupan sekitar dengan memberikan gambaran-gambaran yang dapat dengan mudah dipahami oleh siswa (Oranç \& Küntay, 2019). 
Materi fluida dipilih sebagai materi yang terdapat dalam media pembelajaran Mophy (Monopoly Physics), hal tersebut sesuai dengan rata-rata nilai hasil ulangan tengah semester siswa kelas $X$ materi fluida yang masih dibawah KKM yakni sebesar 69,24. Selain rata-rata nilai yang masih dibawah KKM, siswa juga masih mengalami kebingungan dengan definisi dari fluida sehingga beberapa siswa masih menganggap fluida adalah zat cair, bukan zat alir. Memberikan remidiasi konsep terkait dengan fluida sehingga tercapai pemahaman yang benar hendaknya dapat dikemas dalam sebuah pengalaman belajar yang membuat siswa nyaman dan tidak membosankan. Miskonsepsi terkait dengan fluida sering berdampak kepada sub pokok fludia ini hanya dijelaskan secara konsep matematis dan hapalan semata. Selain itu banyak siswa mengalami kesulitan dalam memecahkan masalah fluida statis dan kesalahan mengaitkan konsep fluida statis dengan konsep lainnya untuk memecahkan persoalan (Ringo dkk., 2019; Rofiqoh dkk., 2015; Rohmah dkk., 2018).

\section{METODE PENELITIAN}

Sampel dalam penenlitian ini adalah siswa kelas X A1 SMK Model PGRI 1 Mejayan sebanyak 30 peserta didik. Prosedur pengumpulan data yang digunakan adalah wawancara, kuesioner dan tes. Wawancara dilakukan untuk memdapatkan informasi terakit kebutuhan siswa dalam proses kegiatan belajar mengajar. Kuesioner yang digunakan antara lain validasi desain dan media dan respon siswa. Tes yang digunakan soal pretest dan postest untuk mengetahui peningkatan pemahaman konsep siswa terhadap materi fisika. soal pretest dan postest yang digunakan dalam bentuk essay sebanyak 5 soal Hasil kuesioner validasi media dan respon siswa dianalisis untuk mengetahui kualitas dari Mophy untuk meningkatkan penguasaan konsep.

Peningkatan penguassan konsep siswa dianalisis menggunakan N-Gain berdasarkan hasil nilai pretest dan postest siswa, yang dirumuskan sebagai berikut:

$$
\mathrm{g}=\frac{S_{\text {post }}-S_{\text {pre }}}{S_{\text {maks }}-S_{\text {pre }}}
$$

Keterangan : $S_{\text {post }}$ : skor yang diperoleh dari hasil postest

$S_{\text {pre }}$ : skor yang diperoleh dari hasil pretest

$S_{\text {maks }}$ : skor maksimal

Tabel 1. Kriteria N-Gain

\begin{tabular}{cc}
\hline Batasan & Kategori \\
\hline$g>0,7$ & Tinggi \\
\hline $0,3 £<g>£ 0,7$ & Sedang \\
\hline$g<0,3$ & Rendah \\
\hline
\end{tabular}

\section{HASIL DAN PEMBAHASAN}

Pada tahap analisis diperoleh informasi terkait kebutuhan siswa, berdasarkan hasil analisis tersebut diketahui bahwa penguasaan konsep pada mata pelajaran fisika siswa tergolong rendah. siswa tidak tertarik dengan mata pelajaran fisika. Pada saat kegiatan pembelajaran fisika berlangsung siswa tidak berpartisipasi secara penuh di kelas, siswa merasa bosan, siswa tidak bertanya terkait materi yang belum dipahami, serta siswa tidak mencatat materi apabila tidak ada intruksi dari guru. Analisis materi bertujuan untuk mengidentifikasi materi yang 
dicantumkan pada media mophy. Materi fluida dipilih sebagai materi yang terdapat dalam media, karena tidak sedikit siswa yang memahami konsep fluida adalah konsep zat cair, padahal pembahasan tersebut dimaksudkan untuk zat alir. Defisini istilah dan pemahaman dasar inilah yang coba diluruskan melalui pengalaman pembelajaran yang interaktif dan menyenangkan. Ketika konsep fluida tidak dipahami dengan benar, maka siswa hanya beranggapan bahwa penjelasan matematis yang dijelaskan oleh guru perlu dihafal saja.

Pada tahap design (perancangan) peneliti membuat rancangan produk mophy, desain produk ini digunakan sebagai acuan dalam mengembangkan produk mophy yang akan dicetak. Setelah membuat rancangan desain, desain divalidasikan kepada ahli desain sebanyak 5 validator. Berdasarkan hasil tersebut desain media layak untuk digunakan. Adapun saran dari ahli desain antara lain (1) Desain uang jangan seperti mata uang Indonesia, (2) Pada papan mophy cantumkan logo Universitas dan Sekolah. Desain media memperoleh rata-rata presentase sebesar $84 \%$, berdasarkan hasil tersebut desain media mophy dinyatakan layak untuk digunakan dan hasil validasi tersebut dapat dilihat pada tabel di bawah ini.

Tabel 1. hasil validasi desain

\begin{tabular}{|c|c|c|c|c|c|c|c|c|c|}
\hline No & $\begin{array}{l}\text { Rancangan } \\
\text { Produk }\end{array}$ & $\begin{array}{l}\text { Ahli } \\
1\end{array}$ & $\begin{array}{r}\text { Ahli } \\
2\end{array}$ & $\begin{array}{l}\text { Ahli } \\
3\end{array}$ & $\begin{array}{l}\text { Ahli } \\
4\end{array}$ & $\begin{array}{l}\text { Ahli } \\
5\end{array}$ & $\begin{array}{l}\sum X \\
\text { per } \\
\text { aspek }\end{array}$ & $\begin{array}{l}X^{-} \text {per } \\
\text { Aspek }\end{array}$ & $\begin{array}{l}\text { Presentase } \\
\text { per skor }\end{array}$ \\
\hline 1 & Papan mophy & 4 & 4 & 4 & 4 & 5 & 21 & 4.2 & 84 \\
\hline 2 & Kartu reward & 4 & 4 & 4 & 4 & 4 & 20 & 4 & 80 \\
\hline 3 & $\begin{array}{l}\text { Kartu } \\
\text { kesempatan }\end{array}$ & 4 & 4 & 4 & 4 & 4 & 20 & 4 & 80 \\
\hline 4 & Pion & 4 & 4 & 4 & 4 & 4 & 20 & 4 & 80 \\
\hline 5 & Dadu & 4 & 5 & 5 & 5 & 4 & 23 & 4.6 & 92 \\
\hline 6 & Uang & 4 & 4 & 5 & 5 & 4 & 22 & 4.2 & 84 \\
\hline 7 & $\begin{array}{l}\text { Kartu } \\
\text { milik }\end{array}$ & 4 & 4 & 4 & 4 & 5 & 21 & 4.4 & 86 \\
\hline Jumlah & & 28 & 29 & 30 & 30 & 30 & 147 & 29.4 & 84 \\
\hline Kriteria & & & & & & & & & Sangat layak \\
\hline
\end{tabular}

Pada tahap development (pengembangan) peneliti mencetak produk mophy sesuai dengan desain yang telah divalidasikan, kemudian media yang dicetak divalidasikan kepada ahli media sebanyak lima ahli media. Saran dari ahli media digunakan untuk memperbaiki produk mophy yang dikembangkan. Adapaun saran dari ahli media tersebut adalah tambah jumlah kartu reward dan kartu kesempatan. Hasil yang diperoleh dari validasi media digunakan untuk mengetahui kelayakan media mophy. Berdasarkan hasil validasi ahli media diperoleh presentase $66,75 \%$ dan dinyatakan layak untuk digunakan. Berikut produk mophy yang telah direvisi sesuai dengan saran dari validator: 

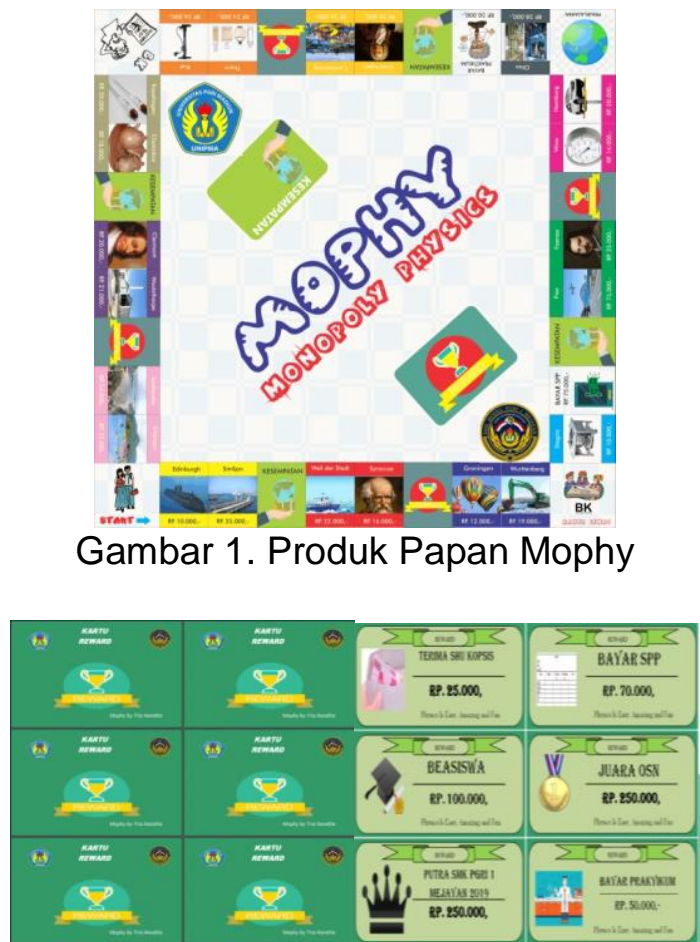

Gambar 2. Produk kartu reward

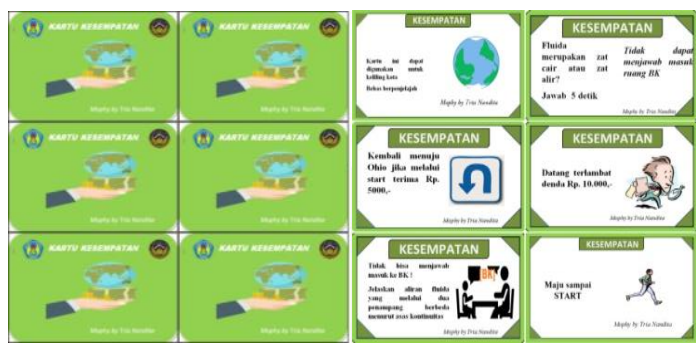

Gambar 3. Produk kartu kesempatan

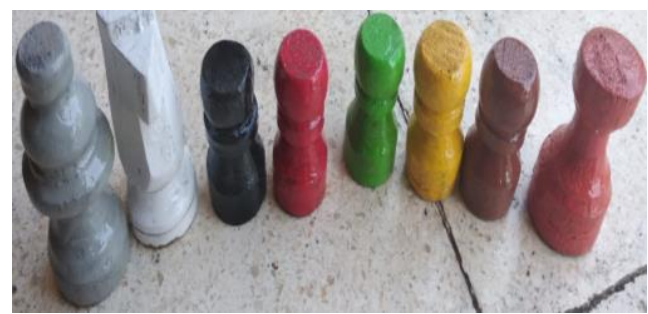

Gambar 4. Produk Pion

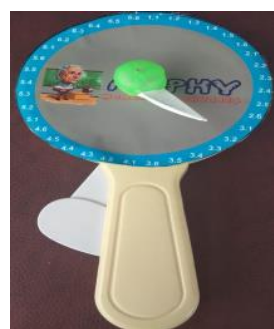

Gambar 5. Alat penentuan giliran bermain 


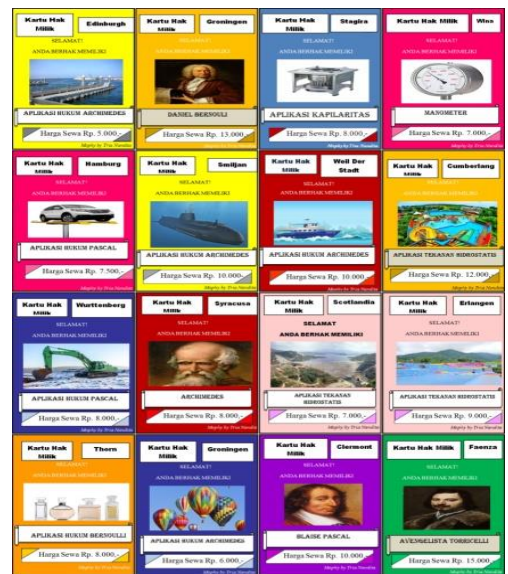

Gambar 6. Produk Kartu Hak Milik

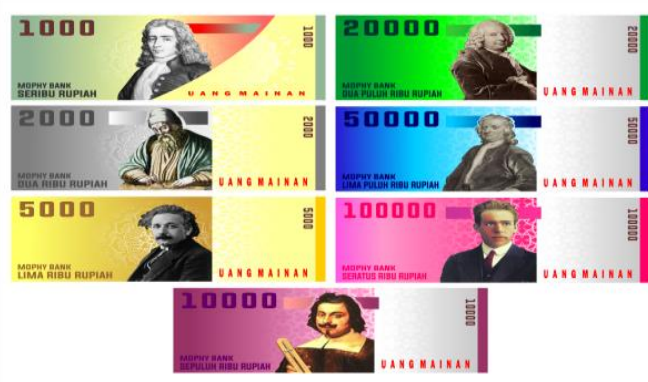

Gambar 7. Produk Uang

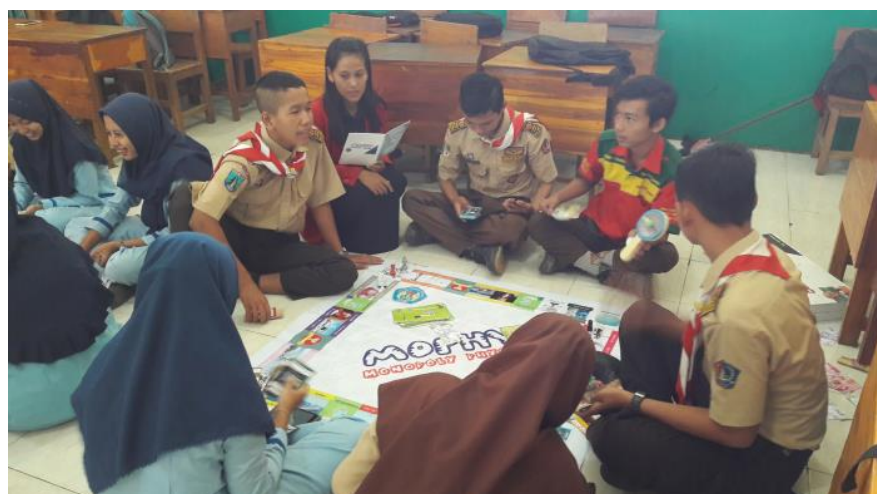

Gambar 8. Uji coba lapangan media Mophy (Monopoly Physics)

Pada tahap implementation (implementasi) merupakan tahap uji coba lapangan. Uji coba dilakukan sebanyak dua kali yaitu uji coba kelas kecil dan uji coba kelas besar. Uji coba kelas besar dilaksanakan pada kelas X C1 SMK Model PGRI 1 Mejayan dengan jumlah siswa 30 siswa. Pada uji coba lapangan dilakukan penyebaran angket respon siswa, hasil dari analisis respon siswa dijadikan untuk menentukan kualitas mophy. Berdasarkan hasil respon siswa diperoleh rata-rata presentase sebesar $77,70 \%$ dan media mophy baik untuk digunakan. Media pembelajaran monopoli berfungsi untuk meningkatkan kualitas belajar siswa. Pada umumnya hasil belajar siswa dengan penggunaan media akan mengendap lebih lama sehingga kualitas dan hasil pembelajaran dapat ditingkatkan. Hal tersebut sesuai dengan hasil penelitian yang dilakukan (Irwan, 2017; Vikagustanti dkk., 2014) yang menyebutkan media monopoli layak digunakan dalam proses pembelajaran IPA dan Fisika. 
Pada tahap evaluation (evaluasi) dilakukan evaluasi terhadap jalannya pembelajaran mengunakan media mophy. Pembelajaran menggunakan media mophy mampu meningkatkan pemahaman konsep siswa kelas X SMK Model PGRI 1 Mejayan. Untuk mengetahui peningkatan pemahaman konsep siswa dilakukan tes ranah kognitif yaitu pretest dan postest. Rata-rata presentase nilai pretest siswa kelas X A1 sebesar 57,33 meningkat menjadi 73,42 sedangkan skala peningkatan pemahaman konsep siswa berdasarkan skor N-Gain diperoleh nilai sebesar 0,38 dan dalam kategori sedang. Nilai $\mathrm{N}$-gain termasuk dalam kategori sedang dikarenakan siswa masih kebingungan tentang tata cara menggunakan media mophy (monopoly physics), dan siswa sedikit bercanda dengan teman lain ketika belajar sembari bermain menggunakan media mophy sehingga siswa kurang serius dalam mengerjakan soal-soal yang tertera dalam media mophy (monopoly physics). Interaksi antara siswa dalam pembelajaran menjadi lebih hidup dikarekan mereka secara tidak langsung sedang melaksanakan pembelajaran yang dikemas dalam sebuah permainan (Purwanto dkk., 2012; Ramadhani \& Wahyuni, 2016).

Soal yang tertera pada media mophy (monopoly physics) mengandung ranah kognitif dari $\mathrm{C} 1$ sampai dengan $\mathrm{C} 4$. Peningkatan penguasaan konsep tertinggi pada ranah kognitif $\mathrm{C} 2$ sebesar $24 \%$, ranah kognitif $\mathrm{C} 1$ mengalami peningkatan sebesar 21\%, ranah kognitif C3 15,5\%, ranah C4 17,5\%. Ranah C2 mengalami peningkatan terbesar dikarena pada media mophy (monopoly physics) terdapat materi fluida yang dapat dibaca oleh siswa melalui kartu reward dan kartu kesempatan sehingga penguasaan konsep siswa mengalami peningkatan. Sedangkan ranah kognitif yang mengalami peningkatan dengan presentase terendah adalah ranah kognitif C3, hal tersebut dikarenakan siswa kekurangan waktu untuk menyelesaikan soal yang tertera pada karu reward dan kesempatan. Demi meningkatkan pembelajaran dikelas guru dituntut untuk terus kreatif, inovatif dan menguprade diri sehingga tercapai kualitas pembelajaran yang diinginkan (Andersen \& Pitkänen, 2019).

Diakhir pertemuan diberikan angket kepada siswa untuk mengetahui respon siswa dalam pembelajaran yang diterapkan. Pertanyaan yang ada diangket adalah pertanyaan terbuka sehingga siswa dapat menuliskan dengan bebas jawaban dari mereka. Beberapa jawaban teratas siswa kita rangkum sebagai berikut:

Saya lebih tertarik belajar fisika dengan kemasan pembelajaran seperti ini.

Belajar sambil bermain sangat menyenangkan dan memudahkan dalam mempelajari materi.

Tidak terasa seperti belajar, menggunakan mophy belajar terasa seperti bermain.

Saya senang belajar dengan mophy karena saya menjadi lebih sering berinteraksi dengan teman dan guru.

\section{KESIMPULAN}

Kualitas media pembelajaran ineraktif mophy (monopoly physics) berdasarkan hasil validasi ahli media dan angket respon siswa layak digunakan. Media interaktif mophy (monopoly physics) memberikan pengaruh positif terhadap penguasaan konsep siswa.

\section{DAFTAR PUSTAKA}


Andersen, H. V., \& Pitkänen, K. (2019). Empowering educators by developing professional practice in digital fabrication and design thinking. International Journal of Child-Computer Interaction, 21, 1-16. https://doi.org/https://doi.org/10.1016/j.ijcci.2019.03.001

Arsyad, A. (2011). Media Pembelajaran. RajaGrafindo Persada.

Eberly, D. H. (2010). Game Physics (Vol. 2nd Edition). Morgan Kaufmann. https://www.sciencedirect.com/book/9780123749031/game-physics

Irwan, D. (2017). Pengembangan Media Permainan (Game) Monopoli Pada Pembelajaran Fisika Materi Besaran Dan Satuan Pada Tingkat Sekolah Menengah Pertama (SMP) UIN Ar-RAniry Banda Aceh]. https://repository.arraniry.ac.id/id/eprint/2519/

Oranç, C., \& Küntay, A. C. (2019). Learning from the real and the virtual worlds: educational use of augmented reality in early childhood. International Journal of Child-Computer Interaction, 21, 104-111. https://doi.org/https://doi.org/10.1016/j.ijcci.2019.06.002

Purwanto, P., Sari, I. M., \& Husna, H. N. (2012). Implementasi Permainan Monopoli Fisika Sebagai Media Pembelajaran Dalam Pembelajaran Kooperatif Tipe TGT Untuk Meningkatkan Prestasi Belajar dan Mengetahui Profil Kemampuan Berpikir Kritis Siswa SMP. Jurnal Pengajaran MIPA, 17(1), 69-76. https://doi.org/http://dx.doi.org/10.18269/jpmipa.v17i1.241

Ramadhani, N., \& Wahyuni, S. (2016). Pengembangan Media Educational Game "Monopoli Fisika Asik (Mosik)" Pada Mata Pelajaran IPA Di SMP. Jurnal

$\begin{array}{ll}\text { Pembelajaran Fisika, } & 5(3), \\ \text { http://jurnal.unej.ac.id/index.php/JPF/article/view/4065 }\end{array}$

Ringo, E. S., Kusairi, S., \& Latifah, E. (2019). Profil Kemampuan Pemecahan Masalah Siswa SMA pada Materi Fluida Statis. Jurnal Pendidikan: Teori, Penelitian, dan Pengembangan, $4(2)$,

178-187. https://doi.org/http://dx.doi.org/10.17977/jptpp.v4i2.11951

Rofiqoh, F., Mahardika, I. K., \& Yushardi, Y. (2015). Pengaruh Model Pembelajaran Kooperatif Tipe Numbered Heads Together (NHT) Disertai Media Monopoli Games Terintegrasi Pendekatan Problem Solving Pada Pembelajaran Fisika di SMA. Jurnal Pembelajaran Fisika, 4(3), 198-203. http://jurnal.unej.ac.id/index.php/JPF/article/view/2637

Rohmah, L., Sri Handono B, P., \& Yushardi, Y. (2018). Analisis siswa dalam memecahkan masalah fisika berdasarkan POLYA pada pokok bahasan fulida statis di SMAN JEMBER. Jurnal Pembelajaran Fisika, 7(4), 328-333. https://doi.org/https://doi.org/10.19184/jpf.v7i4.9653

Sukmawati, E. (2017). Penerapan Media Permainan Science Wiqu Game untuk Meningkatkan Hasil Belajar Siswa pada Materi Perubahan Fisika dan Kimia. PENSA E-JURNAL: PENDIDIKAN SAINS, 5(03). https://jurnalmahasiswa.unesa.ac.id/index.php/pensa/article/view/19816

Sullivan, S., \& Puntambekar, S. (2019). Learning with multiple online texts as part of scientific inquiry in the classroom. Computers \& Education, 128, 36-51. https://doi.org/https://doi.org/10.1016/j.compedu.2018.09.004

Vikagustanti, D. A., Sudarmin, S., \& Pamelasari, S. D. (2014). Pengembangan Media Pembelajaran Monopoli IPA Tema Organisasi Kehidupan Sebagai Sumber Belajar Untuk Siswa SMP. Unnes Science Education Journal, 3(2). https://doi.org/https://doi.org/10.15294/usej.v3i2.3330

Yuniati, L. (2011). Pengembangan media pembelajaran mobile learning efek doppler sebagai alat bantu dalam pembelajaran fisika yang menyenangkan. Jurnal Penelitian Pembelajaran Fisika, 2(2). 